\title{
PERAN FATWA MUI SEBAGAI PRODUK HUKUM ISLAM DALAM MASYARAKAT
}

\author{
Zainul Hakim \\ UIN KH. Achmad Siddiq Jember \\ zainulhakim9@gmail.com
}

\begin{abstract}
Abstrak
Pada Juli 2021, bulan milad MUI yang ke-47, menjadi refleksi capaian peran MUI dalam masyarakat. Setidaknya, MUI memiliki dua kerja penting. Pertama, MUI sebagai pembawa aspirasi dan pelayan umat (khadim al-ummah). Kedua, MUIsebagai mitra pemerintah (shadiq al-hukumah). Dalam menjalankan keduanya, fatwa sebagai keluaran MUI sangat bermanfaat dalam perkembangan hukum Islam di Indonesia. Fatwa yang dihasilkan oleh MUI seperti fatwa tentang hukum keluarga menuju kebutuhan legislasi hukum Islam dalam tatanan sistem hukum Indonesia yang terdapat dalam Undang-undang Nomor 1 Tahun 1974 pada Perkawinan. Sampai kini, tidak kurang dari 15 fatwa yang berkaitan tentang masalah keluarga seperti perkawinan campuran, prosedur pernikahan, pengucapan sighat ta'lik talak pada waktu upacara akad nikah, perkawinan beda agama, kedudukan anak hasil zina, dan lain-lain, termasuk juga rancangan undang pada Hukum Peradilan Agama; dan RUU Hukum Materiil Peradilan Agama Bidang Perkawinan.
\end{abstract}

Kata Kunci: MUI, Fatwa, Hukum Islam, Peraturan Hukum Islam.

\section{Abstract}

On July 2021, MUI's $47^{\text {th }}$ anniversary month, is a reflection of the achievements of MUI's role in society. At least, MUI has two important tasks. First, MUI as a carrier of aspirations and a servant of the people (khadim al-ummah). Second, MUI as a partner of the government (shadiq al-Hukumah). In carrying out both, the fatwa as the output of the MUI is very useful in the development of Islamic law in Indonesia. The fatwa produced by the MUI is like a fatwa on family law towards 
the need for Islamic law legislation in the order of the Indonesian legal system contained in Law Number 1 of 1974 on Marriage. Until now, no less than 15 fatwas related to family issues such as mixed marriages, marriage procedures, the pronunciation of sighat ta'lik talak at the time of the marriage ceremony, interfaith marriages, the position of children resulting from adultery, and others, including the draft law on Religious Court Law; and the draft of the Material Law of the Religious Courts on Marriage.

Keywords: MUI, Fatwa, Islamic Law, Islamic Law Regulations.

\section{Pendahuluan}

Merujuk pada piagam berdirinya Majelis Ulama Indonesia (MUI) yang lahir pada 17 Rajab $1395 \mathrm{H}$ bertepatan dengan 26 Juli 1975 M di Jakarta, dinyatakan bahwa lahirnya MUI bertumpu pada tiga pijakan dasar yakni: Pertama, ditegaskan bahwa MUI berdasarkan Pancasila dan Undang-undang Dasar 1945, pasal 29 ayat (1), para Ulama berkewajiban membina umat Islam untuk lebih bertakwa kepada Tuhan Yang Maha Esa dan turut serta memperkokoh Ketahanan Nasional dan melawan atheisme. Kedua, bahwa berdasar GarisGaris Besar Haluan Negara (GBHN) ditetapkan, hakikat Pembangunan $\mathrm{Na-}$ sional adalah pembangunan manusia seutuhnya, dan pembangunan seluruh masyarakat Indonesia, suatu pembangunan yang seimbang materiil-spiritual dunia dan akhirat. Oleh karena itu, para ulama merasa bertanggung jawab untuk ikut serta mensukseskan Pembangunan Nasional. Ketiga, bahwa berdasar sejarah sejak zaman kolonial para ulama telah merintis adanya persatuan ulama, dan pada dewasa ini diseluruh tanah air telah terbentuk Majelis Ulama Daerah maka dirasa perlu adanya wadah persatuan para ulama seluruh Indonesia, untuk mewujudkan ukhuwah Islamiyah dalam rangka pembinaan persatuan dan kesatuan bangsa Indonesia. ${ }^{1}$

Situasi objektif saat itu menuntut lahirnya suatu majelis yang dapat menghimpun seluruh ulama dari berbagai ormas Islam. Hal ini akan memudahkan pemerintah dan masyarakat dalam mencari dan menemukan "alamat" ulama yang dimaksud. Dengan jumlah ormas Islam yang begitu banyak di Indonesia saat itu dan terus bertambah pada saat ini, memang tidak mudah mendapatkan ulama yang bisa mewakili kepentingan umat ketika berbicara dengan pemerintah, maka MUI hadir untuk kepentingan tersebut.

MUI bukanlah Ormas Islam. MUI merupakan wadahulama, zuama, dan cendekiawan muslim. Dalam kiprahnya, MUI berbagi peran dengan Ormas Islam lain sehingga tidak tabrakan. Misalnya,

\footnotetext{
${ }^{1}$ Dokumentasi Sekretariat MUI, tt, 3.
} 
MUI mendorong arus baru ekonomi syariah di Indonesia, lalu Ormas Islam mendirikan Lembaga Keuangan Syariah, seperti Bank Syariah, Koperasi Syariah dan Lembaga Bisnis Syariah lainnya. ${ }^{2}$

\section{Meluruskan Arah dan Kiprah MUI di Masyarakat}

Dalam kiprahnya di tengah-tengah masyarakat, menurut KH. Ma'ruf Amin, ${ }^{3}$ MUI memainkan dua peran penting. Pertama, sebagai pembawa aspirasi dan pelayan umat (khadim al-ummah). Umat Islam ada di mana-mana dengan kepentingan dan cara beragama dan keberagamaan yang bermacam-macam (dari yang ekstrem atau garis keras, moderat, fundamental hingga lunak). Karena itu, seringkali MUI "terpaksa" harus masuk dalam isu-isu sensitif yang menjadi perhatian publik. Ini pula yang menyebabkan MUI sering dikritik atau bahkan di-bully oleh banyak pihak dan dituduh mengeluarkan fatwa sepihak tanpa mempertimbangkan dampaknya bagi Ormas tertentu, kelompok atau ali-

2 "Sumbangsih dan Peran MUI," Suara Merdeka; www.suaramerdeka.com/smcetak/baca/ 107897/sumbangsih-dan-peran-mui, diakses 9 Desember 2020.

${ }^{3}$ Melalui Munas MUI XI Tahun 2015, KH Ma'ruf Amin terpilih sebagai Ketua Umum MUI Pusat 2015-2020". Saat ini menjabat sebagai Wakil Presiden RI dan sejak 20 Oktober 2019 jabatan tersebut diembankan kepada Plt. Zainut Tauhid Sa'adi yang kini juga menjabat sebagai Wakil Menteri Agama RI 2019-2024. ran tertentu, atau bahkan bagi masyarakat secara umum.

Padahal, sesungguhnya setiap fatwa MUI yang dikeluarkan, pasti telah dikaji oleh para ahli (ulama dan cendekiawan), dan melibatkan profesional berkaitan dengan masalah kajian dimaksud dari berbagai sisi dengan banyak pertimbangan. Namun acapkali, sekali lagi "demi kemaslahatan umat", fatwa MUI harus keluar dengan berbagai risiko tadi. Fatwa sebagai pemandu (taujih) dan petunjuk (irsyad) bagi masyarakat pada kondisi tertentu memang harus ada saat dibutuhkan. Tidak boleh ada persoalan yang mauquf, terbahas tetapi tidak tuntas dan tidak difatwakan, atau malah dibahas saja tidak, maka akan melahirkan persoalan berkepanjangan, apalagi berdampak chaos di tengah masyarakat.

Kedua, bahwa MUI berperan sebagai mitra pemerintah (shadiq al-hukumah). Dalam sejarahnya, ulama dan umara sudah biasa bermitra dan bekerja sama untuk kesejahteraan umat. Sejak sebelum kemerdekaan, Walisongo dan sultan kerajaan Islam Demak bahu membahu untuk mengislamkan tanah Jawa misalnya, pada zaman penjajahan terbukti para ulama mengobarkan semanagat juang menyerukan persatuan dan kesatuan untuk meraih kemerdekaan Indonesia dan mempertahankannya. Demikian juga setelah kemerdekaan dicapai, para ulama tetap 
bahu-membahu dalam mengisi kemerdekaan dengan pembangunan masyarakat seutuhnya, bersama-sama pemerintah sebagai pemegang kedaulatan rakyat juga membutuhkan mitra sebagai penyambung lidah kepada masyarakat luas.

Pada level ini, bermitra atau kerja sama antar keduanya jangan selalu diartikan sebagai perselingkuhan ulama dengan kekuasaan. Ulama yang dekat dengan penguasa jangan buru-buru dicap sebagai ulama su' (buruk). Ulama tidak mungkin selalu beroposisi atau menjauhi pemerintah. Justru banyak dampak negatifnya jika ulama tidak mampu berkomunikasi dan menjalin hubungan baik dengan pemerintah. Dampak buruk paling minimalis adalah; akan terjadi saling curiga jika ulama dan pemerintah tidak pernah saling bertemu, baik pertemuan fisik (silatu al-rahmi) maupun gagasan (silatu alfikri). MUI menyadari betapa penting peran pemerintah dalam membantu tugas ulama, begitu pula sebaliknya. Dalam konteks apa pun, ulama harus mendukung kerja pemerintah sepanjang kebijakan dan program tersebut betulbetul ingin menyejahterakan masyarakat. Namun, tentu ada saatnya, ulama harus berteriak lantang untuk menghentikan pelanggaran dan kesalahan yang dilakukan penguasa.

Dalam sambutan pertamanya, KH. Miftachul Akhyar, ketua terpilih MUI pusat periode 2020-2025 menyampaikan kembali arah khidmah para ulama untuk memegang amanah; amanah dirasiyyah nabawiyyah, amanah yang sangat agung, amanah yang ditunggutunggu oleh umat, bangsa, dan dunia. Dunia sedang menanti kiprah MUI dalam menghadapi era teknologi yang penuh ketidakjelasan, zaman iftiraq atau dalam hadis disebut sebagai yaumu alkharaj. Tugas-tugas para ulama sebagaimana diketahui adalah berdakwah, tidak ada suatu maqam yang lebih tinggi dibandingkan berdakwah. Dakwah itu mengajak bukan mengejek, merangkul bukan memukul, menyayangi bukan menyaingi, mendidik bukan membidik, membina bukan menghina, mencari solusi bukan mencari simpati, membela bukan mencela. Tugas-tugas ini diharapkan mewarnai kehidupan berbangsa dan bernegara pada masa khidmah tahun 2020-2025.

\section{Pola Hubungan Ulama - Umara}

Dalam semua konteks, ulama harus mampu berkomunikasi dengan pemerintah. Hanya pakem atau rambu-rambu yang perlu dijaga adalah independensi ulama, "kode etik" ulama, dan kepentingan umat. Koridornya adalah dekat demi umat, bukan dekat demi kepentingan pribadi. Seberapapun dekatnya

\footnotetext{
${ }^{4}$ Lihat Youtube, https://www.youtube.com/ watch? $\mathrm{v}=\mathrm{jN}$ J8M7So-Wk, diakses 10 Desember 2020.
} 
dengan pemerintah, ulama harus merdeka dan tidak boleh diintervensi oleh penguasa. Jika pemerintah melenceng apalagi sampai mengorbankan kepentingan umat, ulama harus berani mengatakan "tidak" pada pemerintah, seraya memberikan saran dan masukan, kritik yang konstruktif untuk perbaikan, tentu dengan niat yang tulus, dibarengi caracara yang baik penuh rahmah dan keteladanan. Sebaliknya, apabila penguasa melaksanakan tugasnya dengan baik, maka ulama pun tidak ragu untuk memberikan dukungan bahkan apresiasi.

Ulama independen tidak semestinya dipahami sebagai ulama yang tidak pernah menginjakkan kaki ke istana, kantor gubernur, atau pendapa bupati. Mereka boleh saja bolak-balik ke istana, tetapi bukan untuk meminta sumbangan atau "barter" fatwa dengan kepentingan politik. Ulama harus datang ke kantor pemerintah, entah diundang atau tidak, dalam rangka untuk membicarakan kepentingan umat, kepentingan masyarakat bangsa dan negara.

Lerbih lanjut, menurut Hafidhudin, pengabdian MUI tertuang dalam tujuh tugas MUI, yaitu: ${ }^{5}$

1. Sebagai pengawal bagi penganut agama Islam;

5 Didin Hafidhudin, "Tujuh Tugas MUI untuk Mengawal Umat dan Bangsa". Republika Online, 6 September 2015; https://id.wikipedia. org/wiki/Majelis_Ulama_Indonesia, diakses 9 Desember Juli 2020.
2. Sebagai pemberi edukasi dan pembimbing kepada penganut agama Islam;

3. Sebagai penjaring kader-kader yang lebih baik;

4. Sebagai pemberi solusi bagi masalah keagamaan di dunia internasional;

5. Sebagai perumus konsep pendidikan Islam;

6. Sebagai pengawal konten media massa;

7. Sebagai organisasi yang menjalankan kerja sama dengan organisasi keagamaan.

\section{Kiprah MUI pada Bidang Legis- lasi Hukum Islam}

Dalam konteks perkembangan hukum syari'ah di Indonesia, ijtihad dilakukan oleh ahli atau tokoh hukum Islam dan termasuk di dalamnya adalah para ulama, baik dengan ijtihad individu maupun ijtihad kolektif. ${ }^{6}$ Berbagai organisasi Islam seperti NU melalui LBM-nya, Muhammadiyah melalui Majelis Tarjihnya, al-Irsyad, dan lainlain, pada prinsipnya telah melakukan ijtihad kolektif, termasuk dalam hal ini adalah Majelis Ulama Indonesia (MUI). Sejak berdiri pada 1975, MUI telah mengeluarkan sejumlah fatwa dalam ber-

\footnotetext{
${ }^{6}$ Abdul Majid, Ijtihad Kolektif, terj. Syamsuddin (Jakarta: Pustaka al-Kautsar, 1998), 10-12.
} 
bagai bidang kehidupan masyarakat, di antaranya bidang akidah, ibadah, keluarga, makanan, teknologi, ekonomi, politik, dan sebagainya. Tidak dipungkiri bahwa fatwa yang dikeluarkan MUI memang banyak faktor yang mempengaruhi dikeluarkannya fatwa tersebut dan dalam praktiknya fatwa tidak selamanya disambut baik oleh kekuasaan negara, bahkan oleh Ormas-ormas Islam itu sendiri dan masyarakat.

Penelitian Atho Mudzar menyebutkan bahwa fatwa MUI juga dipengaruhi oleh faktor-faktor sosial, politik, kekuasaan, budaya, dan lain-lain. ${ }^{7}$ Sehingga fatwa MUI tidak bisa dikatakan semua hanya semata-mata karena adanya unsur agama. Salah satu fatwa penting yang dikeluarkan MUI adalah fatwa tentang hukum keluarga. Hukum keluarga Islam merupakan bagian penting dan kebutuhan legislasi hukum Islam di dalam tatanan sistem hukum Indonesia. Proses perhatian negara dalam hukum keluarga Islam sudah dimulai sejak zaman kolonial Belanda. Hal tersebut kemudian berlanjut dengan adanya Undangundang No. 1 Tahun 1974 dan sejumlah peraturan hukum keluarga lainnya setelah kemerdekaan. Namun, hal tersebut bukan berarti permasalahan yang terkait dengan hukum keluarga Islam ber-

\footnotetext{
${ }^{7}$ Mohammad Atho Mudzar, "Fatwa-Fatwa Majelis Ulama Indonesia: Sebuah studi tentang Pemikiran Hukum Islam di Indonesia 19751988," Al-Ahkam: Jurnal Ilmu Syariah dan Hukum 3, No. 1 (2018): 87.
}

henti dan sudah final. Dalam praktiknya di masyarakat permasalahan hukum keluarga masih selalu saja muncul dengan berbagai keragaman latar belakang masalah dan tata cara dan coraknya.

Terlepas dari problematika di atas perlu ditegaskan bahwa fatwa merupakan salah satu produk hukum Islam. Produktivitas fatwa yang dihasilkanmerupakan indikator kemajuan atau kelesuan hukum Islam itu sendiri. Hal ini sudah terbukti pada kilas sejarah masa akhir khalifah Daulah Abbasiyah, meredupnya hukum Islam karena sedikitnya fatwa atau ijtihad baru yang dihasilkan karena merasa tercukupinya atas pendapat-pendapat yang di fatwakan oleh imam mujtahid yang sebelumnya. ${ }^{8}$ Ulama saat itu hanya mampu mengikuti para Imam mazhab sebelumnya tanpa kemudian menghasilkan penetapan hukum Islam yang baru. Padahal permasalahan atau perubahan sosial masyarakat terus berjalan dan mengalami perubahan.

Oleh karena itu, berkaitan dengan hukum keluarga, MUI telah mengeluarkan beberapa fatwa dan menjawab berbagai persoalan yang terjadi dalam masyarakat. Paling tidak sampai pada akhir 2020, MUI telah mengeluarkan lebih dari 15 fatwa yang berkaitan tentang masalah keluarga selama kurang

${ }^{8}$ Dedi Supriyadi, Sejarah Hukum Islam: Dari Kawasan Jazirah Arab sampai Indonesia (Bandung: Pustaka, 2010), 115. 
lebih 45 tahun sejak berdiri. Fatwa tersebut antara lain:

1. Perkawinan campuran (1980).

2. Talak tiga sekaligus (1981).

3. Idah wafat (1981).

4. Prosedur pernikahan (1996). Pada UU No. 1 Tahun 1974 dan Kompilasi Hukum Islam, ada pengaturan batas usia kawin. Dan untuk mengakomodir perundang-undangan di Indonesia, MUI juga menegaskan bahwa pernikahan anak usia dini menjadi haram atau tdak sah jika pernikahan ini mengandung unsur madarat.

5. Pengucapan sighat ta'lik talak pada waktu upacara akad nikah (1996).

6. Nikah mut'ah (1997). Ulama dalam komisi fatwa MUI menetapkan bahwa nikah ini haram sebagaimana yang disepakati ulama klasik. Pertimbangan MUI dalam menetapkan fatwa ini adalah konteks sosial masyarakat Indonesia menganut bermazhab Sunni yang secara mengharamkan nikah mut'ah.

7. Perkawinan beda agama (2005).

8. Nikah di bawah tangan (dua kali: 2005 dan 2008), Dalam persoalan ini MUI berupaya mengakomodir pemikiran ulama klasik dengan membolehkan pernikahan bawah tangan ini. Namun, apabila akibat dari pernikahan ini menimbulkan mudarat maka ia menjadi haram.
Penegasan ini tampaknya berupaya mengakomodir aturan perundangundangan yang mengharuskan pencatatan pernikahan pada lembaga terkait.

9. Nikah wisata (2010).

10. RUU Hukum Terapan Peradilan Agama Bidang Perkawinan (2006).

11. RUU Hukum Materill Peradilan Agama Bidang Perkawinan (2009).

12. Kedudukan anak hasil zina dan perlakuan terhadapnya (2012).

13. Kewarisan Beda agama (2005).

14. Beristri lebih dari empat dalam waktu bersamaan (2013). Fatwa MUI tentang poligami tidak memberikan penegasan yang pasti terkait dengan asas perkawinan. Berdasarkan pada Fatwa Nomor 17 Tahun 2013, MUI membolehkan berpoligami sampai batas maksimal empat orang istri. MUI hanya berpandangan haram hukumnya beristri lebih dari empat perempuan pada waktu yang bersamaan. Fatwa ini menunjukkan bahwa praktik poligami boleh dan sah apabila pernikahan dengan istri pertama hingga keempat dilaksanakan sesuai syarat dan rukun.

15. Seputar masalah donor air susu ibu atau istirdla' (2013).

16. Lesbian, gay, sodomi, dan pencabulan (2014).

Dari sekian fatwa yang dikeluarkan MUI di atas, maka latar belakang yang 
mendorong munculnya fatwa dapat diklasifikasikan menjadi tiga kelompok. Pertama, fatwa yang muncul karena adanya fenomena yang terjadi di tengah masyarakat. Kedua, fatwa yang muncul sebagai reaksi atas putusan hakim dalam berbagi persidangan. Ketiga, fatwa yang muncul sebab ada permintaan negara dalam penyusunan peraturan perundang-undangan.

Studi kasus terkait dengan fatwa MUI yang pertama yang disebabkan oleh fenomena yang ada di masyarakat adalah tentang perkawinan beda agama pada sekitar tahun 2005. Perdebatan ini sebenarnya sudah muncul sebelum kemerderkaan Indonesia. Isu perkawinan beda agama kemudian menimbulkan polemik kembali pada era tahun 80-an. Beberapa perkawinan antara lain, yaitu Jamal Mirdad dan Lidya Kandow, setelah itu diikuti oleh pasangan aktivis agama Nurcholish dan Ang Mei Yong pada Juni 2003.

Dalam fakta sebenarnya praktik perkawinan beda agama seakan tidak berhenti bahkan terus ada dengan berbagai bentuk. Namun, setidaknya dua perkawinan inilah yang kemudian menjadikan masyarakat Muslim bertanya tentang hukum perkawinan beda agama saat itu karena muncul dari kalangan selebritis dan tokoh. Fatwa MUI tentang perkawinan beda agama selalu menjadi referensi baik dalam itu pro dan kontra terhadap kasus perkawinan beda agama.
Para pelaku dan pendukung perkawinan beda agama berdalih bahwa hal tersebut sah dengan alasan hak asasi manusia dan maslahah. Sementara di sisi lain, MUI mempertahankan pendapat bahwa agama harus menjadi rujukan utama dalam menciptakan mewujudkan dan memelihara ketenteraman kehidupan berumah tangga. ${ }^{9}$ Akhirnya, MUI memberikan pendapat tentang perkawinan beda agama di Mahkamah Konstitusi (MK). Hal ini disebabkan oleh adanya sejumlah pihak yang mengajukan $y u$ dicial review terhadap pasal 2 ayat (1) UU Perkawinan yang berkaitan erat perkawinan beda agama. ${ }^{10}$

Pemberian pendapat dalam sidang MK menunjukkan bahwa MUI dipandang sebagai perwakilan pemikiran hukum Islam, mewakili umat Islam dalam berpendapat mengenai hukum Islam. Kedudukan MUI memang tidak terikat, namun fatwa MUI tidak bisa disepelekan dalam mengemban amanat keumatan sebagai lembaga yang merekayasa sosial. Fatwa ataupun pendapat MUI tentang perkawinan beda agama telah sah dan didengar oleh masyarakat muslim bahkan hakim yang mewakili negara. MUI sebenarnya telah mampu membangun dalam mengatur masyarakat melalui fatwa yang telah di-

\footnotetext{
${ }^{9}$ Fatwa Majelis Ulama Indonesia Nomor 4/ MUNAS VII/ MUI/8/2005 tentang Perkawinan Beda Agama.

10 Putusan Mahkamah Konstitusi No. 68/ PUU-XII/2014: 110- 122
} 
tetapkan. Selain itu, fatwa juga telah mampu menegaskan bahwa UU perkawinan sudah sesuai dengan hukum fikih Islam dan tidak perlu diubahdengan berbagai alasan.

Studi kasus fatwa MUI yang kedua adalah peran fatwa MUI No. 11 Tahun 2012 tentang kedudukan anak hasil zina dan perlakuan terhadapnya. Fatwa ini merupakan respons dari adanya putusan Mahkamah Konstitusi tentang uji materiil UU perkawinan. Putusan MK Nomor 46/PUU-VIII/2010 tersebut pada intinya mengatur kedudukan anak yang dilahirkan di luar perkawinan mempunyai hubungan perdata dengan ibunya dan keluarga ibunya serta dengan laki-laki sebagai ayahnya yang dapat dibuktikan berdasarkan ilmu pengetahuan dan teknologi dan/ atau alat bukti lain menurut hukum mempunyai hubungan darah, termasuk hubungan perdata dengan keluarga ayahnya. Pada kasus ini, fatwa MUI dapat menjawab keresahan masyarakat dan menegaskan tentang kedudukan anak hasil zina. MUI seakan menegaskan bahwa umat Islam tidak perlu rancu dengan putusan MK. Bukan hanya itu, bahkan terkait dengan ketundukannya terhadap putusan MK, MUI juga menegaskan bahwa umat Islam harus tetap berpegang teguh kepada syariat Islam dan bukan kepada hukum yang dibuat oleh manusia. ${ }^{11}$

11 "Fatwa Mui tentang Kedudukan Anak

\section{Kedudukan dan Peran Fatwa MUI dalam Proses Legislasi Hukum Islam}

Perlu ditekankan bahwa fatwa MUI yang muncul dari masyarakat sebenarnya bukan hal yang baru dalam kajian fikih. Namun, fatwa ditetapkan karena kegelisahan masyarakat dalam menyikapi kebijakan aturan negara. Hal ini menunjukkan bahwa hukum Islam dalam bentuk fatwa ini muncul dari bawah ke atas (bottom up) yang bersifat dinamis dan kasuistis. Hal ini bisa diamati bahwa sebenarnya dalam isi fatwa tersebut bukan hanya berisi tentang kedudukan anak hasil zina baik dari nasab, waris, dan wali nikah dari anak hasil zina. Namun, melalui jalur itu MUI juga memberikan rekomendasi terhadap DPR dan pemerintah. Artinya, MUI meminta agar disusun peraturan perundang-undangan yang mengatur hukuman bagi pelaku zina dan memasukkan zina sebagai delik hukum. MUI juga meminta kepada pemerintah agar mencegah terjadinya perzinaan dengan tegas dan keras, dan melindungi anak hasil zina, dan mencegah penelantaran. ${ }^{12}$

Hasil Zina dan Perlakuan terhadapnya," VOAIslam, 22 Maret 2012; http://www.voa-islam. com/read/indonesiana/2012/03/22/18307/ fatwa-mui-tentang-kedudukan-anak-hasilzina-dan-perlakuan-terhadapnya, diakses pada 9 Desember 2020.

12 Fatwa Majelis Ulama Indonesia Nomor 11 Tahun 2012 tentang Kedudukan Anak Hasil Zina dan Perlakuan terhadapnya. 
Kenyataan ini sekilas fatwa MUI seolah-olah tidak pro dengan negara dalam upaya perlindungan anak. Tetapi, jika ditelaah lebih lanjut sebenarnya fatwa MUI juga memiliki perlindungan terhadap anak hasil zina. ${ }^{13}$ Melalui putusan hakim, negara memberikan dengan kalimat pasal-pasal perundangundangan yang lebih kuat dan lebih mengikat. Sementara itu, fatwa MUI merekayasa sosial dengan lebih menekankan dengan pemikiran hukum Islam dan menanggapi putusan $\mathrm{MK}$ dengan sejumlah rekomendasi dalam rangka pembangunan hukum keluarga yang lebih progresif tetapi masih dalam bingkai ke-Islaman.

Peran MUI dalam upaya menciptakan keluarga sakinah, mawadah, dan warahmah, muncul kembali setelah hasil MUNAS MUI menghasilkan fatwa keharaman nikah mut'ah. Pernikahan ini juga disebut dengan nikah wisata karena sering terjadi di tempat tempat pariwisata. Beberapa tempat yang sering ditemukan adanya nikah wisata ini antara lain seperti di Ciawi, Megamendung, Ciasura, dan Cianjur. Prakteknya biasanya wanita berasal dari Indonesia, dan laki-laki dari luar negeri terutama dari Timur Tengah. Sedang-

13 Ali, "Ini Dia Fatwa MUI tentang Anak Hasil Zina," Hukumonline.com, 16 Maret 2012http://www.hukumonline.com/berita/ baca/lt4f632f5e9f2fa/ini-dia-fatwa-muitentang-anak-hasil-zina, diakses pada 28 Juli 2020. kan di daerah tersebut juga terdapat praktik nikah siri yang dilakukan oleh sesama warga negara Indonesia (WNI). Keduanya memang terjadi di kawasan Puncak dan sama-sama tidak tercatat di Kantor Urusan Agama (KUA). Sistem pembagian mahar pun kerap kali transaksinya terjadi antara wanita dengan makelar dalam beberapa kasus perkawinan di atas. ${ }^{14}$

Fatwa sebagai produk hukum Islam sangat berperan penting terhadap perkembangan hukum Islam dan social enginering (rekayasa sosial). Sifat fatwa yang dinamis, dan responsif menjadikan fatwa menjadi lebih mudah diterima apalagi pada saat terjadi kekosongan ketentuan atau belum diatur secara jelas di dalam hukum negara. Selain itu, tingkat dimensi keadilan dalam perspektif Tuhan (Allah) yang menyatu dengan dimensi keadilan sosial dianggap menjadi sebuah hal yang menarik dan diimani sebagai sesuatu yang benar dan wajib diikuti. Sehingga fatwa menjadi bagian norma dalam masyarakat yang diyakini kebenarannya memiliki sanksi sebagaimana norma hukum. Sekalipun sifat fatwa MUI tidak mengikat, tetapi pelaksanaan dan ketaatan seseorang kepada fatwa dikembalikan kepada setiap individu masing-masing dan juga tanpa

\footnotetext{
${ }^{14}$ Fatah Hidayat, "Dinamika Perkembangan Hukum Keluarga di Indonesia," An-Nisa' 9, No. 2 (Desember 2014).
} 
sanksi secara langsung dari negara. Walaupun demikian, setidaknya fatwa MUI mampu melakukan upaya penafsiran atau penjelasan terhadap banyak hal yang dihadapai oleh masyarakat muslim khususnya di Indonesia.

\section{Simpulan}

Demikian MUI memiliki peran dan kontribusi dalam bidang pergulatan hukum di Indonesia. Di samping itu, terdapat masih banyak lagi peran MUI, salah satunya adalah andil besar MUI dalam berkontribusi memberikan perlindungan kepada umat/masyarakat muslim untuk mendapatkan kepastian hokum halal dalam menggunakan berbagai produk makanan, obat-obatan dan kosmetik dengan melakukan sertifikasi kehalalan. Secara khusus lembaga tersebut bernama: Lembaga Pengkajian Pangan, Obat-obatan, dan Kosmetika Majelis Ulama Indonesia atau yang disebut LPPOM MUI.

LPPOM MUI adalah lembaga yang bertugas kuat untuk meneliti, mengkaji, menganalisis, dan memutuskan apakah produk-produk baik pangan, minuman dan turunannya, obat-obatan dan produk kosmetika apakah aman dikonsumsi baik dari sisi kesehatan dan dari sisi pengajaran agama Islam yakni halal atau boleh-tidak bolehnya dan baik atau tidak baiknya untuk dikonsumsi bagi umat Muslim khususnya di wilayah Indonesia, selain itu lembagia ini juga memberikan layanan pendampingan, rekomendasi, merumuskan ketentuan dan bimbingan kepada masyarakat agar membangun kesadaran dan mengonsumsi produk-produk yang halalan dan thayyiban.

Pembentukan LPPOM MUI didasarkan atas mandat dari Pemerintah/ negara agar MUI berperan aktif dalam meredakan kasus yang mengindikasikan beredarnya lemak babi di Indonesia pada 1988. LPPOM MUI didirikan pada 6 Januari 1989 untuk melakukan pemeriksaan dan sertifikasi halal.

Langkah-langkah terus diikhtiarkan untuk memperkuat posisi LPPOM MUI menjalankan fungsi sertifikasi halal, maka pada 1996 ditandatangani Nota Kesepakatan Kerjasama antara Departemen Agama, Departemen Kesehatan dan MUI. Nota kesepakatan tersebut lalu disusul dengan penerbitan Keputusan Menteri Agama (KMA) 518 Tahun 2001 dan KMA 519 Tahun 2001, yang menguatkan MUI sebagai lembaga sertifikasi halal serta melakukan pemeriksaan (audit), penetapan fatwa, dan menerbitkan sertifikat halal.

Sebagai lembaga otonomi bentukan MUI, LPPOM MUI tidak berjalan sendiri. Keduanya memiliki kaitan erat dengan lembaga-lembaga lain dalam mengeluarkan keputusan. Maka, sertifikat Halal merupakan langkah yang berhasil dijalankan sampai sekarang. Di dalamnya tertulis fatwa halal MUI 
yang menyatakan kehalalan suatu produk sesuai dengan syarikat Islam dan menjadi syarat pencantuman labelan halal dalam setiap produk makanan minuman, obat-obatan, dan kosmetika. Syarat kehalalan produk tersebut meliputi:

1. Tidak mengandung DNA babi dan bahan-bahan yang berasal tradisional dari babi;

2. Tidak mengandung bahan-bahan yang diharamkan seperti; darah hewan;

3. Semua bahan yang berasal dari hewan yang disembelih sesuai dengan syariat Islam. Hal ini yang kemudian juga melahirkan inisiasi untuk melakukan sertifikasi kepada para jagal dan rumah penyembelihan hewan;

4. Semua tempat penyimpanan tempat penjualan pengolahan dan transportasinya tidak boleh digunakan untuk daging babi; apabila pernah digunakan untuk daging babi atau barang yang tidak halal lainnya terlebih dahulu dibersihkan dengan tata cara yang diatur sesuai syariat Islam. $^{15}$

Selain mengadakan sertifikasi halal di tingkat nasional, LPPOM MUI juga mengadakan kerjasama dengan lemba-

15 “LPPOM MUI", https://id.wikipedia.org/ wiki/LPPOM_MUI, diakses pada 28 Desember 2020 . ga sertifikasi halal di berbagai belahan dunia melalui Dewan Halal Dunia atau World Halal Council (WHC) yang dirintis sejak 6 Desember 1999. Tema besar yang diangkat dewan ini adalah masalah standardisasi halal termasuk prosedur maupun sertifikasinya, mengingat organisasi yang mengeluarkan sertifikat di berbagai negara memiliki prosedur dan standar yang berbedabeda. WHC menerapkan sertifikasi dan standardisasi halal yang digunakan di Indonesia. WHC berniat mengajukan standar halal kepada lembaga internasional World Trade Organization (WTO). Kantor WHC berada di Jakarta. Saat ini WHFC mempunyai anggota sebanyak 35 lembaga sertifikasi halal dari 19 negara.

\section{Daftar Pustaka}

"LPPOM MUI." Https://id.wikipedia. org/wiki/LPPOM_MUI. Diakses 28 Desember 2020.

"Majelis Ulama Indonesia." Https:// id.wikipedia.org/wiki/Majelis_ Ulama_Indonesia. iakses 28 Desember 2020.

"Fatwa MUI tentang Kedudukan Anak Hasil Zina dan Perlakuan terhadapnya." VOA-Islam, 22 Maret 2012; http://www.voa-islam. com/read/indonesiana/2012/03/ 22/18307/fatwa-mui-tentangkedudukan-anak-hasil-zina-dan- 
perlakuan-terhadapnya. Diakses pada 9 Desember 2020.

"Sumbangsih dan Peran MUI." Suara Merdeka; https://suaramerdeka. com/smcetak/baca/107897/ sumbangsih-dan-peran-mui. Diakses 9 Desember 2020.

Ali. "Ini Dia Fatwa MUI tentang Anak Hasil Zina." Hukumonline.com, 16 Maret 2012. Http://hukumonline. com/berita/baca/lt4f632f5e9f2fa/ ini-dia-fatwa-mui-tentang-anakhasil-zina. Diakses pada 28 Juli 2020.

Asy-Syarafi, Abdul Majid. Ijtihad Kolektif. trans. Syamsuddin, Jakarta: Pustaka al-Kautsar, 1998.

Dokumentasi Sekretariat MUI, tt, 3

Fatah, Rohadi Abdul. Analisis Fatwa Keagamaan dalam Fikih Islam. Jakarta: Bumi Aksara, 2006.

Ghofur, Abdul and Sulistiyono. "Peran Ulama dalam Legislasi Modern Hukum Islam.” Asy-Syir'ah: Jurnal Ilmu Syariah dan Hukum 49, No. 1, Desember 2014.

Hafidhudin, Didin. "Tujuh Tugas MUI untuk Mengawal Umat dan Bangsa." Republika Online, 6 September 2015; https://id.wikipedia.org/ wiki/Majelis_Ulama_Indonesia. Diakses 9 Desember Juli 2020.

Hidayat, Fatah. "Dinamika Perkembangan Hukum Keluarga di Indo- nesia." An-Nisa' 9. No. 2. Desember 2014 .

https://www.youtube.com/watch? $\mathrm{v}=\mathrm{jNJ} 8 \mathrm{M} 7 \mathrm{So}-\mathrm{Wk}$. Diakses 10 Desember 2020.

Majelis Ulama Indonesia. Himpunan Fatwa Majelis Ulama Indonesia tentang Ibadah. Jakarta: Erlangga, 2014.

- Fatwa Majelis Ulama Indonesia Nomor 4/MUNAS VII/ MUI/8/2005 tentang Perkawinan Beda Agama.

. Fatwa Majelis Ulama Indonesia, Nomor 11 Tahun 2012 tentang Kedudukan Anak Hasil Zina dan Perlakuan terhadapnya.

- Himpunan Fatwa MUI sejak 1975. Jakarta: Erlangga, 2011.

Mudzar, Mohammad Atho. Fatwa-fatwa Majelis Ulama Indonesia: Sebuah studi tentang Pemikiran Hukum Islam di Indonesia 1975-1988. trans. Soedarso Soekarno. Jakarta: INIS, 1993.

Putusan Mahkamah Konstitusi No. 68/ PUU-XII/2014.

Rasyid, Hamdan. "Optimalisasi Peran Mui Sebagai Mufti "Resmi” Indonesia di tengah Benturan Liberalisme dan Fundamentalisme," in Fatwa Majelis Ulama Indonesia (MUI) dalam Perspektif Hukum dan Perundang-Undangan. Jakar- 
ZAINUL HAKIM

ta: Puslitbang Lektur dan Khazanah Keagamaan Badan Litbang dan Diklat Kementerian Agama RI, 2012.

Supriyadi, Dedi. Sejarah Hukum Islam: Dari Kawasan Jazirah Arab sampai Indonesia. Bandung: Pustaka, 2010. 